OPEN ACCESS

Edited by:

Heber C. Nielsen,

Tufts Medical Center, United States

Reviewed by:

Sajeev Job,

Cambridge University Hospitals,

United Kingdom

Ömer Erdeve

Ankara University, Turkey

*Correspondence:

Aparna Patra

apatra0129@gmail.com

Specialty section:

This article was submitted to

Neonatology,

a section of the journal

Frontiers in Pediatrics

Received: 31 December 2020

Accepted: 05 February 2021

Published: 25 February 2021

Citation:

Patra A, Thakkar PS, Makhoul M and

Bada HS (2021) Objective

Assessment of Physiologic Alterations

Associated With Hemodynamically

Significant Patent Ductus Arteriosus in Extremely Premature Neonates.

Front. Pediatr. 9:648584.

doi: 10.3389/fped.2021.648584

\section{Objective Assessment of Physiologic Alterations Associated With Hemodynamically Significant Patent Ductus Arteriosus in Extremely Premature Neonates}

\author{
Aparna Patra ${ }^{1 *}$, Pratibha S. Thakkar ${ }^{1}$, Majd Makhoul ${ }^{2}$ and Henrietta S. Bada ${ }^{1}$ \\ ${ }^{1}$ Division of Neonatology, Department of Pediatrics, Kentucky Children's Hospital, University of Kentucky, Lexington, KY, \\ United States, ${ }^{2}$ Division of Pediatric Cardiology, Department of Pediatrics, Kentucky Children's Hospital, University of \\ Kentucky, Lexington, KY, United States
}

Delay in closure of ductus arteriosus in postnatal life may lead to serious consequences and complications in an extremely premature neonate secondary to hemodynamic alterations in regional blood flow pattern in various organs. Despite the widespread recognition amongst neonatologists to identify a hemodynamically significant patent ductus arteriosus (hSPDA) early in the postnatal course, there is lack of consensus in its definition and thus the threshold to initiate treatment. Echocardiographic assessment of PDA shunt size and volume combined with neonatologists' impression of clinical significance is most frequently used to determine the need for treatment of PDA. Common clinical signs of hsPDA utilized as surrogate for decreased tissue perfusion may lag behind early echocardiographic signs. Although echocardiogram allows direct assessment of PDA shunt and hemodynamic alterations in the heart, it is limited by dependence on pediatric cardiologist availability, interobserver variation and isolated time point assessment. Electrical cardiometry $(E C)$ is a non-invasive continuous real time measurement of cardiac output by applying changes in thoracic electrical impedance. EC has been validated in preterm newborns by concomitant transthoracic echocardiogram assessments and may be beneficial in studying changes in cardiac output in premature newborns with hsPDA. Alterations in perfusion index derived from continuous pulse oximetry monitoring has been used to study changes in cardiac performance and tissue perfusion in infants with PDA. Near infrared spectroscopy (NIRS) has been used to objectively and continuously assess variations in renal, mesenteric, and cerebral oxygen saturation and thus perfusion changes due to diastolic vascular steal from hsPDA in preterm neonates. Doppler ultrasound studies measuring resistive indices in cerebral circulation indicate disturbance in cerebral perfusion secondary to ductal steal. With recent trends of change in practice toward less intervention in care of preterm newborn, treatment strategy needs to be targeted for select preterm population most vulnerable to 
adverse hemodynamic effects of PDA. Integration of these novel ways of hemodynamic and tissue perfusion assessment in routine clinical care may help mitigate the challenges in defining and targeting treatment of hsPDA thereby improving outcomes in extremely premature neonates.

Keywords: hsPDA, preterm, physiologic, echocardiogram, near-infrared spectroscopy, electrical cardiometry

\section{INTRODUCTION}

Ductus arteriosus is an important and necessary structure for the fetus. It allows communication between the pulmonary artery and descending aorta during fetal life facilitating majority of right ventricular output to bypass the pulmonary vascular bed and enter the descending aorta supporting systemic oxygenation. Delay in its postnatal closure as commonly encountered in extremely premature infants born $<28$ weeks gestation (1) can result in failure of circulatory adaptation leading to hemodynamic alterations in regional blood flow pattern in multiple organs and serious complications in both early and late postnatal course. A recent retrospective study examining the incidence of patent ductus arteriosus (PDA) in extremely premature babies found highest rate of $93 \%$ in infants born at $23-24$ weeks, $64 \%$ in $25-26$ weeks, and $21 \%$ in $27-28$ weeks of gestation (2).

The clinical consequences depend on the degree of leftto-right shunting through the PDA and ductal steal. The increase in pulmonary blood flow in the setting of prematurity can lead to pulmonary edema, pulmonary hemorrhage, respiratory deterioration, pulmonary hypertension, left atrial and ventricular overload and dilation followed by left ventricular dysfunction (3, 4). Diminished gastrointestinal, renal, and cerebral blood flow secondary to PDA has been historically linked to increased risk of necrotizing enterocolitis, isolated intestinal perforation; acute kidney injury and intraventricular hemorrhage, respectively (5). The above adverse hemodynamic effects have led to the widespread recognition of identifying a hemodynamically significant PDA (hsPDA), however there is lack of consensus in its definition. Previously published trials used variable definitions or lacked specific treatment criteria or included more mature gestational ages and hence the optimal threshold to identify the infants at the highest risk of the above adverse sequelae is not well-delineated (5-7).

Persistent patency of hsPDA is indisputably associated with increased morbidity and mortality in premature neonates. However, there is debate whether early medical or surgical closure of PDA improves outcomes. Hence, in the last decade, approach to PDA has shifted from early treatment to watchful waiting for spontaneous closure (8). A recent pilot exploratory trial showed similar ductal persistence rates at discharge when early PDA intervention strategy was compared to targeted therapy in presence of persistent hsPDA at $\geq 7$ days of life. Extremely premature neonates of gestational age $\geq 26$ weeks managed with routine early treatment approach in the first week of life had higher incidence of late-onset sepsis and longer duration to achieve full enteral feeds with no advantage of reducing morbidities or ductal ligation incidence at discharge. Selective waiting and targeted approach to PDA management although reasonable in some extremely premature babies, may lead to prolonged exposure to ductal shunt and its associated detrimental effects particularly in gestational age $<26$ weeks (9). Data from Pediatric Hospital Information System demonstrated a temporal association between declining pharmacotherapy for PDA and unadjusted increases in long term pulmonary and neurological impairment among extremely low birth weight neonates (10). Therefore, in the current era when neonates born as early as 22 weeks are surviving, neonatologists find themselves vacillating and wavering in their decision of management of PDA.

Currently echocardiographic measurements of a PDA are considered as gold standard for assessing the magnitude and relevance of left to right shunting in premature newborns (11). Many authors have established echocardiographic criteria for hemodynamic significance of a PDA (11-13). Echocardiography gives information of a single time point and is limited by dependence on availability of a pediatric cardiologist and interobserver variation. Also, the vulnerability of the patient to the PDA is incompletely assessed by an echocardiogram with regards to disturbances in organ blood flow and adverse hemodynamic effect in other organs which is critical in assessing need for treatment. The clinical signs of alteration in organ perfusion such as widening pulse pressure, decreased mean blood pressure, fluctuations in heart rate, hypoxemia, oliguria, worsening metabolic acidosis and increasing respiratory support lack clinical sensitivity (14) and may lag behind the early hemodynamic effects noted on echocardiography $(15,16)$. Continuous assessment and accurate interpretation of the variations and fluctuations in physiological parameters associated with hsPDA can aid in timely diagnosis and management. Current biomedical sophistication and advancement allows processing of physiologic signals in preterm neonate caused by failed circulatory adaptation and hemodynamic effects of PDA. In this review, we discuss the various novel techniques that may complement or improve the assessment of hemodynamic alterations in PDA; these methods have been examined and validated in clinical studies which can further our knowledge about the hemodynamic vulnerability of a neonate with hsPDA.

\section{Arterial Blood Pressure and the Dilemma of Systemic Hypotension in hsPDA}

Arterial blood pressure (BP) is one of the commonly used physiologic signals for evaluating hemodynamic status associated with any clinical condition. Invasive arterial catheter is the 
gold standard for measuring arterial $\mathrm{BP}$ in the initial course of premature newborn followed by oscillometric monitoring. There are technical concerns with inaccurate and under or over estimation of BP with either methods in this population $(17,18)$ however its low cost, uncomplicated technique and feasibility in small sized premature newborns makes it widely used in the neonatal intensive care unit. Normogram for mean invasive BP based on gestational and postnatal age has been established in neonates (19) and most commonly practiced hypotension criteria is mean arterial pressure less than infant's postmenstrual age (20). Extremely premature infants are predisposed to low mean blood pressure in immediate postnatal period due to myocardial and autonomic immaturity which may be further exacerbated by foramen ovale or ductal shunting. Blood pressure changes secondary to hsPDA may initially manifest as decrease in diastolic BP relative to systolic BP and eventually followed by reduction in both systolic and diastolic BP $(21,22)$. However, $\mathrm{BP}$ in sick ventilated preterm newborns does not always correlate with central blood flow, organ perfusion and oxygen delivery and may be associated with normal or high cardiac output (23-25) making sole reliance on BP for assessment of hemodynamic magnitude of PDA not useful. Also threshold for intervention for hypotension in preterm population varies widely amongst neonatologists (26) due to variable evidence about long term neurodevelopmental effects with hypotension tolerance vs. treatment (27-29). Further, as mentioned above, changes in $\mathrm{BP}$, clinical signs of hypotension and compromised systemic perfusion may have a later onset compared to early signs of ductal steal on echocardiogram. Thus, a more precise and individualized approach for early determination of hemodynamic magnitude of PDA is required in the truly vulnerable micro preemie.

\section{Neonatologist Performed Targeted Echocardiography}

Echocardiography is the gold standard of predicting and diagnosing hemodynamic significance of PDA. hsPDA may go clinically unnoticed in initial postnatal course of a preterm neonate as clinicals signs of hsPDA lag behind echocardiographic measurements by mean of 2 days (16). Performance of bedsidetargeted echocardiography by neonatologists (also known as functional echocardiography $\mathrm{fECHO}$ ) is gaining popularity in contemporary neonatal clinical practice to assist in early diagnosis and enhance medical decision making although its use continues to be limited in the United States (30).

The European special interest group for Neonatologist Performed Echocardiography (31) describes specific parameters to objectively quantify the hemodynamic magnitude and relevance of PDA. Transductal dimension (measured at the narrowest site on the pulmonary end), shunt direction, ratio of systolic to diastolic shunt flow velocity and transductal pressure gradient are important determinants of shunt volume. Higher transductal shunt volumes are associated with increased pulmonary and decreased systemic perfusion. Further comprehensive objective measurements of pulmonary over circulation can be estimated from left ventricular output and parameters of left sided volume (left atrium/aortic root ratio, left pulmonary artery diastolic flow velocity) and pressure load that possibly explains associated morbidities such as pulmonary hemorrhage, high need for respiratory support, and later risk of bronchopulmonary dysplasia. Large volume of interatrial shunts may artificially lower left atrium/aortic root ratio or left ventricular end diastolic volume and should be carefully evaluated (32). The impact of systemic hypoperfusion secondary to ductal steal can be assessed by the flow direction of forward, absent or reverse in descending aorta, celiac trunk and middle cerebral artery during diastole. Transductal diameter $\geq 1.5 \mathrm{~mm}$ in initial $31 \mathrm{~h}$ of life, first appearance of doppler pulsatile ductal flow pattern, and ratio of systolic to diastolic ductal flow velocity $>1.9$ in the first $48 \mathrm{~h}$ are the parameters with high sensitivity and specificity for predicting patency of ductus arteriosus (32-37). Ductal diameter and left ventricular output are frequently used to determine need of therapeutic intervention for hsPDA $(34,38)$. Repeated assessment of above parameters on fECHO and monitoring trends can help evaluate and establish diagnosis of hsPDA.

Various scoring systems, incorporating measurements from fECHO have been published to standardize the assessment of hemodynamic severity of the PDA $(12,38)$. These scoring systems utilizing fECHO parameters have been seen to decrease risk of in hospital mortality (39) and or pulmonary hemorrhage $(39,40)$ or chronic lung disease $(38)$ in preterm infants treated for hsPDA. Additionally, use of fECHO during treatment may help in monitoring response to medication minimizing drug doses and adverse effects from pharmacotherapy $(41,42)$. Many of these fECHO measurements are subjective to interobserver variations (43) and the need for additional prolonged training (44) of neonatologists have limited its use in clinical settings despite high value in clinical decision making. Repeated assessment of discussed parameters on $\mathrm{EECHO}$ and monitoring trends rather than following absolute cut off values may be beneficial in evaluation of hsPDA.

\section{Electrical Cardiometry-An Adjunct to Echocardiogram With Continuous Data}

Assessment of the hemodynamic status particularly cardiac function is crucial for understanding the hemodynamic impact of hsPDA in preterm neonates. In neonatal practice, invasive blood pressure is routinely and continuously monitored in initial days of life for premature infants followed by intermittent noninvasive oscillometric blood pressure monitoring. Assessment of cardiac output (CO) by interpretation of indirect variables like blood pressure can be unreliable in premature and sick neonates (45). Other reliable invasive method of measuring cardiac output utilizing thermodilution catheter is not clinically feasible in extremely premature neonates and the limitations of sporadic information from technically demanding and operator dependent echocardiogram has been previously discussed.

Electrical Cardiometry (EC, also known as electrical velocimetry) has been proposed as a safe, well-tolerated, practical, non-invasive, continuous method of measurement of cardiac output that is reproducible in neonates of various gestational maturity, weight and body surface area $(46,47)$. 
EC works on the principle of electrical bioimpedance which is calculated based on the variation in aortic blood flow using surface adhesive electrodes placed on the neck or scapular area and thorax (48). Forward flow during systole causes unidirectional configuration of erythrocytes parallel to blood flow which results in better conductivity. During diastolic filling stage, there is abrupt cessation of this blood flow leading to haphazard arrangement of erythrocytes which increases the impedance and dampens the conductivity. This difference in impedance creates a waveform which is utilized to measure blood velocity, stroke volume and cardiac output (49, 50). Clinical feasibility and application of EC has been studied in animal models (51), adult humans (52), pediatric congenital heart disease patients (53), and in more recent years in term and preterm neonates $(47,48,54-56)$.

Authors have established the validity of EC by demonstrating that stroke volume and cardiac output measured by EC are comparable with echocardiogram with estimated similar bias, precision and acceptable percentage error in neonates (47, 54, 57). These studies investigated preterm infants with hsPDA (variable definition based on ductal size and left atrium aortic root ratio) and found that EC cardiac output measurements were clinically interchangeable with echocardiogram findings. Another recent study utilized EC as one of the parameters for early prediction of hsPDA in a cohort of neonates $<32$ weeks gestation. The authors found that a trend of increased left ventricular output on EC at $6 \mathrm{~h}$ of life correlated with hsPDA requiring pharmacotherapy (7).

Despite the accumulating evidence of clinically advantageous and acceptable values between EC and echocardiogram in hemodynamic assessment of hsPDA, it is important to note that reference values of premature neonate cardiac function on EC is yet under research and not clinically established (56). Also larger percentage of error in EC measurements is a concern in babies on invasive mechanical ventilation particularly on high frequency ventilation which is commonly used in clinical practice for critically sick extremely premature neonates $(54,56)$. Another limitation of EC in hemodynamic assessment of hsPDA is it fails to measure preload or intravascular volume (56) which is important to know to prevent injudicious volume expansion in these patients who are at high risk of intracranial hemorrhage. The integration of EC in clinical neonatology hence is currently limited to trending cardiac function and the hemodynamic impact rather than making clinical decision on absolute values.

\section{Near-Infrared Spectroscopy and Regional Oxygenation}

One of the important aspects of hemodynamic disturbance in hsPDA is the "diastolic run-off" that leads to attenuated blood flow to various peripheral organs (58). Oxygen delivery to tissues depends on blood flow and oxygen content which is reduced in these circumstances resulting in decreased regional oxygen saturation $\left(\mathrm{RSO}_{2}\right)$ in multiple organs particularly cerebral $\left(\mathrm{cRSO}_{2}\right)$, renal $\left(\mathrm{rRSO}_{2}\right)$, and splanchnic beds $\left(\mathrm{sRSO}_{2}\right)$ necessitating physiological increase in fractional tissue oxygen extraction (FTOE) to maintain tissue oxygen requirement in premature neonates. Use of NIRS has progressed from being a research tool to clinical bedside device for non-invasive, continuous assessment of this changing oxygen dynamics in presence of hsPDA (59-61) as well as other clinical applications in neonatology.

NIRS technology uses light from infrared spectrum with wavelength between 700 and 1,000 nm. As light passes through the tissue, it is partly absorbed, reflected and scattered. Probes comprising of transmitter and receiver optodes applied on skin, detects the reflected portion of light which varies depending on the absorptive capacity of the molecules present. NIRS measures oxygen saturation by assessing the relative amount of oxyhemoglobin and deoxyhemoglobin content in the tissue (62). Due to deeper penetrance of infrared light in the tissue, signal for NIRS is derived from all vascular beds with major contribution from venous compartment (75\%) followed by arterial and capillary (20 and 5\% (63) which makes NIRS measurements specific and reflective of regional tissue oxygen balance by calculating oxygen delivery and consumption (62). Unlike pulse oximetry that calculates arterial oxygen saturation, NIRS provides information on alteration in tissue oxygen consumption which may be an early marker of perfusion injury $(62,64)$ making it complementary to pulse oximetry.

Specialized flexible mini-sensors as well as smaller sized adult sensors are available for use in neonates (65) that can be applied on the skin surface on forehead, flank region and periumbilical region to assess $\mathrm{cRSO}_{2}, \mathrm{rRSO}_{2}$, and $\mathrm{sRSO}_{2}$, respectively (66). Reference values of various sensors used in neonates have been published (67). Various authors have published reference ranges for $\mathrm{cRSO}_{2}$ starting from birth through initial weeks of life and advancing postnatal age for both term (68-70) and preterm infants $(71,72)$. Gestational age stratified normative values for $\mathrm{CRSO}_{2}$ in preterm neonates $<32$ weeks have been validated for use in first $72 \mathrm{~h}$ of life (65).

NIRS monitoring can aid in early recognition of hsPDA by identifying the magnitude of compromise in renal, cerebral and mesenteric circulation. Studies have reported decreased $\mathrm{rRSO}_{2}$ level of $61 \pm 3 \%$ is associated with hsPDA with further decreased level of $<43 \%$ predicting the need for PDA closure $(73,74)$. Positive correlation was noted between ductal size and persistently low $\mathrm{CRSO}_{2}$ levels in infants with ductal patency irrespective of its hemodynamic relevance (75). Prolonged exposure to lower cerebral oxygenation as seen in infants with persistent patency of ductus requiring surgical closure is associated with impaired brain growth and poor neurodevelopmental outcomes $(76,77)$.

Additional utility of NIRS may be in monitoring of tissue perfusion during and following pharmacotherapy or surgical intervention for hsPDA. Studies have shown prompt improvement in cerebral and mesenteric perfusion after pharmacological and surgical closure of PDA $(78,79)$. Brief improvements in end-organ perfusion may be followed by reduction in regional blood flow in post ductal ligation patients owing to decreased left ventricular cardiac output. Continuous and concurrent monitoring of regional oxygenation in brain and kidneys perioperatively may enable clinicians to diagnose post ligation cardiac syndrome before the onset 
of clinical symptoms related to decreased left ventricular output (80).

\section{Perfusion Index and Alteration in Peripheral Perfusion}

There is growing controversial evidence in the neonatal literature that arterial blood pressure may not be a reliable indicator for estimation of peripheral perfusion in a premature neonate (81, 82). Early identification of compromised peripheral perfusion in a premature neonate with PDA is important for clinical decision making about its hemodynamic impact. Goal of minimizing handling in such patient cohort makes serial echocardiogram difficult to perform.

Peripheral pulse-oximetry is a routinely and readily applied monitoring device for premature neonates which does not require any special preparation or handling. Pulse oximeters generate a photoplethysmography waveform at infrared and red wavelengths. Perfusion index (PI) is a non-invasive method of objectively measuring peripheral perfusion from the plethysmography signal generated by pulse oximeters and represents the ratio of light absorbed by pulsatile elements such as arteries and non-pulsatile elements such as blood in venous or capillary bed, bone, connective tissue etc. $(83,84)$. PI has been shown to be an objective indicator of hemodynamic alterations and correlate with peripheral perfusion, cardiac output, and stroke volume $(84,85)$.
Studies have examined PI values in healthy and sick term neonates (86) as well as preterm infants (87) with an aim to derive normative values. Authors have also demonstrated PI values in first week of life in babies with ductal dependent circulation (88). Difference in PI measurements between right upper extremity (pre ductal) and either of lower extremities (post ductal) may be indicative of poor post ductal perfusion and thus suggestive of presence of hsPDA (89). Changes in PI can also be affected by changes in skin temperature at monitoring site (84).

Decrease in superior vena cava (SVC) flow may be a novel marker of compromised systemic circulation in neonates with hsPDA (90). PI has been shown to correlate with SVC flow in premature neonates and has been associated with volume responsiveness in sick neonates $(91,92)$. Even though increased pulsatile component from bounding pulses in hsPDA can falsely increase PI more than true perfusion, authors found the correlation of PI with SVC flow remains valid discerning the hemodynamic impact of the PDA in a cohort of premature newborns born $<32$ weeks of gestation (91).

Other authors reported that the PI of the lower extremities (post-ductal) is decreased compared to the right arm (preductal) in preterm infants with hsPDA which measured by delta PI of a certain cut off value strongly correlated with the echocardiographic diagnosis of hsPDA (93). In another study that reviewed the relation of PI and PDA, authors noted that delta PI, delta PI variability, and mean pre-ductal PI measured $4 \mathrm{~h}$ prior to echocardiography reliably detected PDA in preterm

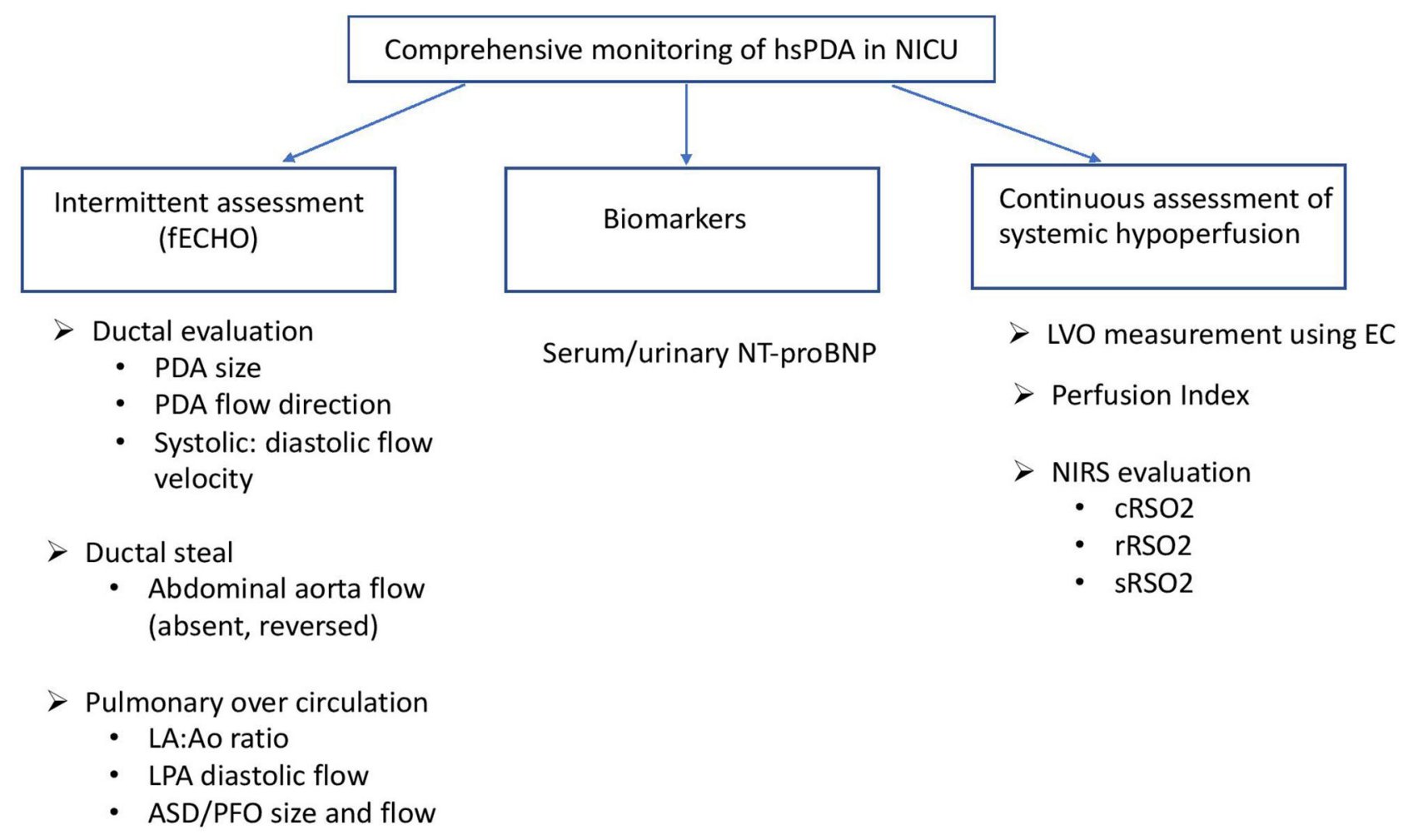

FIGURE 1 | Monitoring of hsPDA in the NICU. fECHO, functional echocardiogram; LA, left atrium; Ao, aortic root; LPA, left pulmonary artery; ASD, atrial septal defect; PFO, patent foramen ovale; LVO, left ventricular output; EC, electrical cardiometry; NIRS, near infrared spectroscopy; $\mathrm{CRSO}_{2}$, cerebral regional oxygen saturation; $\mathrm{rRSO}_{2}$, renal regional oxygen saturation; $\mathrm{SRSO}_{2}$, splanchnic regional oxygen saturation. 
infants (94). PI is a simple, continuous dynamic measure of peripheral perfusion which may be a useful adjunct in helping identify preterm babies vulnerable to circulatory adversities of a hsPDA.

\section{Other Biomarkers for Early Detection}

The review of physiologic alterations secondary to hsPDA would be incomplete without discussion of certain biomarkers that have been studied and incorporated in clinical practice for assessment of hemodynamic significance of PDA. Cardiac peptides such as B-type (Brain) natriuretic peptide (BNP) and N-terminal pro-BNP(NT-proBNP) have been studied extensively for early detection as well as monitoring therapy of hsPDA. NT-pro BNP is a marker of heart failure that increases due to ventricular volume and pressure overload in hsPDA. Normative values for this peptide in plasma in first week of life has been studied at various gestational ages, with lower normal values noted in

TABLE 1 | Advantages and limitations of methods for bedside hemodynamic monitoring of PDA in Neonatal ICU.

\begin{tabular}{|c|c|c|}
\hline $\begin{array}{l}\text { Monitoring } \\
\text { modality }\end{array}$ & Advantages & Disadvantages \\
\hline $\begin{array}{l}\text { Arterial blood } \\
\text { pressure }\end{array}$ & $\begin{array}{l}\text { - Widely used } \\
\text { - Low cost } \\
\text { - Accurate blood } \\
\text { pressure measurement }\end{array}$ & $\begin{array}{l}\text { - Invasive } \\
\text { - Does not measure organ } \\
\text { perfusion/oxygen delivery } \\
\text { - Detects late sign of hsPDA }\end{array}$ \\
\hline $\begin{array}{l}\text { Targeted } \\
\text { echocardiograph }\end{array}$ & $\begin{array}{l}\text { - Early assessment of PDA } \\
\text { ny hemodynamics } \\
\text { - Established reference values } \\
\text { available } \\
\text { - Independent of } \\
\text { cardiologist's availability }\end{array}$ & $\begin{array}{l}\text { - Interobserver variation } \\
\text { - Need for extensive training } \\
\text { for neonatologists }\end{array}$ \\
\hline $\begin{array}{l}\text { Electrical } \\
\text { cardiometry }\end{array}$ & $\begin{array}{l}\text { - Non-invasive } \\
\text { - Continuous monitoring of } \\
\text { cardiac function } \\
\text { - Precise values comparable to } \\
\text { echocardiography } \\
\text { - Assess early signs of hsPDA } \\
\text { (change in LVCO) }\end{array}$ & $\begin{array}{l}\text { - Evolving reference values in } \\
\text { preterm } \\
\text { - Discrepancy in neonates on } \\
\text { invasive high } \\
\text { frequency ventilation }\end{array}$ \\
\hline NIRS & $\begin{array}{l}\text { - Continuous monitoring } \\
\text { - Non invasive } \\
\text { - Assessment of peripheral } \\
\text { organ perfusion } \\
\text { - Multiple site assessment } \\
\text { - Trend monitoring }\end{array}$ & $\begin{array}{l}\text { - Evolving site specific } \\
\text { reference values in preterm } \\
\text { - Lack of absolute } \\
\text { threshold values }\end{array}$ \\
\hline $\begin{array}{l}\text { Perfusion } \\
\text { index }\end{array}$ & $\begin{array}{l}\text { - Widely available } \\
\text { - Continuous monitoring } \\
\text { - Non-invasive } \\
\text { - Correlates with change in } \\
\text { organ blood flow } \\
\text { - Trend monitoring }\end{array}$ & $\begin{array}{l}\text { - Lack of absolute } \\
\text { threshold values }\end{array}$ \\
\hline $\begin{array}{l}\text { Biomarkers } \\
\text { NT-proBNP } \\
\text { nucleated } \\
\text { RBC count } \\
\text { platelet count }\end{array}$ & $\begin{array}{l}\text { - Widely available } \\
\text { - Correlation between serum } \\
\text { and urinary NT-proBNP }\end{array}$ & $\begin{array}{l}\text { - Abnormal values are not } \\
\text { specific to PDA }\end{array}$ \\
\hline
\end{tabular}

hSPDA, hemodynamically significant patent ductus arteriosus; LVCO, left ventricular cardiac output; NT-proBNP, N-terminal B-type natriuretic peptide; NIRS, near infrared spectroscopy. term infants compared to preterms (95). Various authors have examined the association of plasma BNP and NT-proBNP levels with echocardiographic parameters of hemodynamic significance $(96,97)$. Serum cut off values have been investigated for early detection of hemodynamic significance by day of life 3 (98), predicting probability of spontaneous ductal closure (99) and developing a scoring system for PDA and associated outcomes (100). Further non-invasive avenues have been explored recently with study of urinary NT-proBNP to predict ductal diameter (101) and non-response to pharmacotherapy $(102,103)$. Patients with medically treated hsPDA can have persistently elevated urinary NT-proBNP levels and NT-proBNP/creatinine ratio on day of life 14 indicative of cardiac strain secondary to residual volume overload from ductal shunt beyond its pharmacological closure (104).

Alterations of organ perfusion associated with hsPDA can lead to production of ischemia modified albumin, serum levels of which were found to be elevated in cohort of preterm neonates with hsPDA (105). Relationship of end tidal carbon monoxide measured non-invasively in exhaled gas and hsPDA has been studied in preterm infants as carbon monoxide is a known regulator of muscle relaxation and may be implicated in the physiologic closure of ductus arteriosus. Higher end tidal carbon monoxide levels early after birth was associated with hsPDA secondary to relaxant effect of carbon monoxide on ductal muscular tone (106).

Elevated nucleated red blood cell (NRBC) count at birth is related to chronic uterine hypoxia which may predispose to PDA. A recent prospective study of preterm infants, showed differences in absolute NRBC count with ductal size and hemodynamic significance of PDA as measured by echocardiogram. The authors proposed cut off absolute NRBC levels to predict hsPDA (107).

There is ambiguous data on association of thrombocytopenia with hsPDA and its influence on response to treatment. Presence of low platelet count and high platelet distribution width in preterm neonates is shown to be associated with hsPDA (108). There is report of neonates with platelet dysfunction (as measured by platelet function analyzer-100) to have prolonged ductal patency as detected on echocardiography in first 72-96 h of life (109).

\section{CONCLUSION}

The definition of hsPDA and the population it applies to, continues to develop and unfold with accumulation of further evidence of novel ways of assessment and outcomes. This review discusses the role of various continuous modes of tapping and analyzing physiologic variables resulting from a hsPDA beyond the cardiologist's echocardiogram as summarized in Figure 1. Such continuous monitoring allows better and earlier understanding of the magnitude of ductal shunting by assessing the vulnerability of organs at risk of over-circulation or hypoperfusion. There is emerging evidence that routine and widespread treatment for PDA in preterm infants is not necessarily associated with improved outcomes (110). However, 
there is a cohort of extremely premature infants of the most immature gestation with need for precise and deliberate approach for early identification of severe hemodynamic disturbance associated with hsPDA in the first week of life. Further research for risk stratification to identify this select cohort of neonates is needed. Advantages and limitations of various modalities for ductal hemodynamic monitoring has been summarized in Table $\mathbf{1}$. The continuous complementary data for monitoring of this hemodynamic disturbance is encouraging, however prior to integration in clinical care, the question whether assessment of these parameters and resulting interventions lead to enhancement in short- or long-term outcomes will need to be

\section{REFERENCES}

1. Hamrick SE, Hansmann G. Patent ductus arteriosus of the preterm infant. Pediatrics. (2010) 125:1020-30. doi: 10.1542/peds.2009-3506

2. Sung SI, Chang YS, Kim J, Choi JH, Ahn SY, Park WS. Natural evolution of ductus arteriosus with noninterventional conservative management in extremely preterm infants born at 23-28 weeks of gestation. PLoS ONE. (2019) 14:e0212256. doi: 10.1371/journal.pone.0212256

3. Bancalari E. Patent ductus arteriosus and short- and long-term respiratory outcomes. Am J Perinatol. (2016) 33:1055-7. doi: 10.1055/s-0036-1586112

4. Clyman RI. Patent ductus arteriosus, its treatments, and the risks of pulmonary morbidity. Semin Perinatol. (2018) 42:235-42. doi: 10.1053/j.semperi.2018.05.006

5. Jain A, Shah PS. Diagnosis, evaluation, and management of patent ductus arteriosus in preterm neonates. JAMA Pediatr. (2015) 169:863-72. doi: 10.1001/jamapediatrics.2015.0987

6. Mitra S, Rønnestad A, Holmstrøm H. Management of patent ductus arteriosus in preterm infants-where do we stand? Congenit Heart Dis. (2013) 8:500-12. doi: 10.1111/chd.12143

7. Katheria V, Poeltler DM, Brown MK, Hassen KO, Patel D, Rich W, et al. Early prediction of a significant patent ductus arteriosus in infants <32 weeks gestational age. J Neonatal Perinatal Med. (2018) 11:265-71. doi: $10.3233 / \mathrm{npm}-1771$

8. Gillam-Krakauer M, Hagadorn JI, Reese J. Pharmacological closure of the patent ductus arteriosus: when treatment still makes sense. J Perinatol. (2019) 39:1439-41. doi: 10.1038/s41372-019-0518-3

9. Clyman RI, Liebowitz M, Kaempf J, Erdeve O, Bulbul A, Håkansson S, et al. PDA-TOLERATE trial: an exploratory randomized controlled trial of treatment of moderate-to-large patent ductus arteriosus at 1 week of age. $J$ Pediatr. (2019) 205:41-8.e6. doi: 10.1016/j.jpeds.2018.09.012

10. Hagadorn JI, Brownell EA, Trzaski JM, Johnson KR, Lainwala S, Campbell BT, et al. Trends and variation in management and outcomes of very low-birth-weight infants with patent ductus arteriosus. Pediatr Res. (2016) 80:785-92. doi: 10.1038/pr.2016.166

11. Zonnenberg I, de Waal K. The definition of a haemodynamic significant duct in randomized controlled trials: a systematic literature review. Acta Paediatr. (2012) 101:247-51. doi: 10.1111/j.1651-2227.2011.02468.x

12. McNamara PJ, Sehgal A. Towards rational management of the patent ductus arteriosus: the need for disease staging. Arch Dis Child Fetal Neonatal Ed. (2007) 92:F424-7. doi: 10.1136/adc.2007.118117

13. Schena F, Francescato G, Cappelleri A, Picciolli I, Mayer A, Mosca F, et al. Association between hemodynamically significant patent ductus arteriosus and bronchopulmonary dysplasia. J Pediatr. (2015) 166:1488-92. doi: 10.1016/j.jpeds.2015.03.012

14. Davis P, Turner-Gomes S, Cunningham K, Way C, Roberts R, Schmidt B. Precision and accuracy of clinical and radiological signs in premature infants at risk of patent ductus arteriosus. Arch Pediatr Adolesc Med. (1995) 149:1136-41. doi: 10.1001/archpedi.1995.02170230090013

15. Benitz WE. Patent ductus arteriosus in preterm infants. Pediatrics. (2016) 137:e20153730. doi: 10.1542/peds.2015-3730 answered. Also, with most of these parameters lacking established reference values in preterm neonates, currently they are useful at the bedside primarily for trending of physiologic alterations specific to a patient rather than indicating treatment threshold.

\section{AUTHOR CONTRIBUTIONS}

AP conceived the idea for the article, reviewed the current literature, and wrote the manuscript. PT reviewed the literature and assisted in writing various sections of the manuscript. MM and $\mathrm{HB}$ critically reviewed the manuscript. All authors reviewed the final manuscript.

16. Skelton R, Evans N, Smythe J. A blinded comparison of clinical and echocardiographic evaluation of the preterm infant for patent ductus arteriosus. J Paediatr Child Health. (1994) 30:406-11. doi: 10.1111/j.1440-1754.1994.tb00689.x

17. Weindling AM. Blood pressure monitoring in the newborn. Arch Dis Child. (1989) 64(4 Spec No):444-7. doi: 10.1136/adc.64.4_spec_no.444

18. Diprose GK, Evans DH, Archer LN, Levene MI. Dinamap fails to detect hypotension in very low birthweight infants. Arch Dis Child. (1986) 61:771-3. doi: 10.1136/adc.61.8.771

19. Nuntnarumit P, Yang W, Bada-Ellzey HS. Blood pressure measurements in the newborn. Clin Perinatol. (1999) 26:981-96, x

20. Fanaroff JM, Fanaroff AA. Blood pressure disorders in the neonate: hypotension and hypertension. Semin Fetal Neonatal Med. (2006) 11:174-81. doi: 10.1016/j.siny.2006.01.002

21. Evans N, Moorcraft J. Effect of patency of the ductus arteriosus on blood pressure in very preterm infants. Arch Dis Child. (1992) 67(10 Spec No):1169-73. doi: 10.1136/adc.67.10_spec_no.1169

22. Sarkar S, Dechert R, Schumacher RE, Donn SM. Is refractory hypotension in preterm infants a manifestation of early ductal shunting? J Perinatol. (2007) 27:353-8. doi: 10.1038/sj.jp.7211749

23. Wright IM, Goodall SR. Blood pressure and blood volume in preterm infants. Arch Dis Child Fetal Neonatal Ed. (1994) 70:F230-1. doi: $10.1136 /$ fn.70.3.f230-a

24. Kluckow M, Evans N. Relationship between blood pressure and cardiac output in preterm infants requiring mechanical ventilation. J Pediatr. (1996) 129:506-12. doi: 10.1016/s0022-3476(96)70114-2

25. Pladys P, Wodey E, Beuchée A, Branger B, Bétrémieux P. Left ventricle output and mean arterial blood pressure in preterm infants during the 1st day of life. Eur J Pediatr. (1999) 158:817-24. doi: 10.1007/s004310051213

26. Dempsey EM, Barrington KJ. Treating hypotension in the preterm infant: when and with what: a critical and systematic review. J Perinatol. (2007) 27:469-78. doi: 10.1038/sj.jp.7211774

27. Kuint J, Barak M, Morag I, Maayan-Metzger A. Early treated hypotension and outcome in very low birth weight infants. Neonatology. (2009) 95:311-6. doi: 10.1159/000180113

28. St Peter D, Gandy C, Hoffman SB. Hypotension and adverse outcomes in prematurity: comparing definitions. Neonatology. (2017) 111:228-33. doi: 10.1159/000452616

29. Faust K, Härtel C, Preuß M, Rabe H, Roll C, Emeis M, et al. Short-term outcome of very-low-birthweight infants with arterial hypotension in the first $24 \mathrm{~h}$ of life. Arch Dis Child Fetal Neonatal Ed. (2015) 100:F388-92. doi: 10.1136/archdischild-2014-306483

30. Giesinger RE, Stanford AH, Rios DR, Bhombal S, Fraga MV, Levy VY, et al. Targeted neonatal echocardiography in the United States of America: the contemporary perspective and challenges to implementation. Pediatr Res. (2019) 85:919-21. doi: 10.1038/s41390-0190338-3

31. van Laere D, van Overmeire B, Gupta S, El-Khuffash A, Savoia M, McNamara PJ, et al. Application of NPE in the assessment of a patent ductus arteriosus. Pediatr Res. (2018) 84(Suppl 1):46-56. doi: 10.1038/s41390-018-0077-x 
32. Singh Y, Fraisse A, Erdeve O, Atasay B. Echocardiographic diagnosis and hemodynamic evaluation of patent ductus arteriosus in extremely low gestational age newborn (ELGAN) infants. Front Pediatr. (2020) 8:573627. doi: 10.3389/fped.2020.573627

33. Harling S, Hansen-Pupp I, Baigi A, Pesonen E. Echocardiographic prediction of patent ductus arteriosus in need of therapeutic intervention. Acta Paediatr. (2011) 100:231-5. doi: 10.1111/j.1651-2227.2010.02027.x

34. Kluckow M, Evans N. Early echocardiographic prediction of symptomatic patent ductus arteriosus in preterm infants undergoing mechanical ventilation. J Pediatr. (1995) 127:774-9. doi: 10.1016/s0022-3476(95)70172-9

35. Thankavel PP, Rosenfeld CR, Christie L, Ramaciotti C. Early echocardiographic prediction of ductal closure in neonates $\leq 30$ weeks gestation. J Perinatol. (2013) 33:45-51. doi: 10.1038/jp.2012.41

36. Polat TB, Celik IH, Erdeve O. Early predictive echocardiographic features of hemodynamically significant patent ductus arteriosus in preterm VLBW infants. Pediatr Int. (2016) 58:589-94. doi: 10.1111/ped.12915

37. Kwinta P, Rudziński A, Kruczek P, Kordon Z, Pietrzyk JJ. Can early echocardiographic findings predict patent ductus arteriosus? Neonatology. (2009) 95:141-8. doi: 10.1159/000153098

38. El-Khuffash A, James AT, Corcoran JD, Dicker P, Franklin O, Elsayed $\mathrm{YN}$, et al. A patent ductus arteriosus severity score predicts chronic lung disease or death before discharge. J Pediatr. (2015) 167:1354-61.e2. doi: 10.1016/j.jpeds.2015.09.028

39. Rozé JC, Cambonie G, Marchand-Martin L, Gournay V, Durrmeyer X, Durox $\mathrm{M}$, et al. Association between early screening for patent ductus arteriosus and in-hospital mortality among extremely preterm infants. JAMA. (2015) 313:2441-8. doi: 10.1001/jama.2015.6734

40. Kluckow M. Use of ultrasound in the haemodynamic assessment of the sick neonate. Arch Dis Child Fetal Neonatal Ed. (2014) 99:F332-7. doi: 10.1136/archdischild-2013-304926

41. Bravo MC, Cabañas F, Riera J, Pérez-Fernández E, Quero J, PérezRodríguez J, et al. Randomised controlled clinical trial of standard versus echocardiographically guided ibuprofen treatment for patent ductus arteriosus in preterm infants: a pilot study. J Matern Fetal Neonatal Med. (2014) 27:904-9. doi: 10.3109/14767058.2013.846312

42. Carmo KB, Evans N, Paradisis M. Duration of indomethacin treatment of the preterm patent ductus arteriosus as directed by echocardiography. J Pediatr. (2009) 155:819-22.e1. doi: 10.1016/j.jpeds.2009.06.013

43. Schwarz CE, Preusche A, Baden W, Poets CF, Franz AR. Repeatability of echocardiographic parameters to evaluate the hemodynamic relevance of patent ductus arteriosus in preterm infants: a prospective observational study. BMC Pediatr. (2016) 16:18. doi: 10.1186/s12887-016-0552-7

44. Sehgal A, Paul E, Menahem S. Functional echocardiography in staging for ductal disease severity: role in predicting outcomes. Eur J Pediatr. (2013) 172:179-84. doi: 10.1007/s00431-012-1851-0

45. de Boode WP. Cardiac output monitoring in newborns. Early Hum Dev. (2010) 86:143-8. doi: 10.1016/j.earlhumdev.2010.01.032

46. Soleymani S, Borzage M, Noori S, Seri I. Neonatal hemodynamics: monitoring, data acquisition and analysis. Expert Rev Med Devices. (2012) 9:501-11. doi: 10.1586/erd.12.32

47. Noori S, Drabu B, Soleymani S, Seri I. Continuous non-invasive cardiac output measurements in the neonate by electrical velocimetry: a comparison with echocardiography. Arch Dis Child Fetal Neonatal Ed. (2012) 97:F340-3. doi: 10.1136/fetalneonatal-2011-301090

48. Weisz DE, Jain A, McNamara PJ, A EL-K. Non-invasive cardiac output monitoring in neonates using bioreactance: a comparison with echocardiography. Neonatology. (2012) 102:61-7. doi: 10.1159/0003 37295

49. Osypka MJ, Bernstein DP. Electrophysiologic principles and theory of stroke volume determination by thoracic electrical bioimpedance. AACN Clin Issues. (1999) 10:385-99. doi: 10.1097/00044067-199908000-00008

50. Summers RL, Shoemaker WC, Peacock WF, Ander DS, Coleman TG. Bench to bedside: electrophysiologic and clinical principles of noninvasive hemodynamic monitoring using impedance cardiography. Acad Emerg Med. (2003) 10:669-80. doi: 10.1111/j.1553-2712.2003.tb00054.x

51. Osthaus WA, Huber D, Beck C, Winterhalter M, Boethig D, Wessel A, et al. Comparison of electrical velocimetry and transpulmonary thermodilution for measuring cardiac output in piglets. Paediatr Anaesth. (2007) 17:749-55. doi: 10.1111/j.1460-9592.2007.02210.x

52. Zoremba N, Bickenbach J, Krauss B, Rossaint R, Kuhlen R, Schälte G. Comparison of electrical velocimetry and thermodilution techniques for the measurement of cardiac output. Acta Anaesthesiol Scand. (2007) 51:1314-9. doi: 10.1111/j.1399-6576.2007.01445.x

53. Norozi K, Beck C, Osthaus WA, Wille I, Wessel A, Bertram H. Electrical velocimetry for measuring cardiac output in children with congenital heart disease. Br J Anaesth. (2008) 100:88-94. doi: 10.1093/bja/aem320

54. Song R, Rich W, Kim JH, Finer NN, Katheria AC. The use of electrical cardiometry for continuous cardiac output monitoring in preterm neonates: a validation study. Am J Perinatol. (2014) 31:1105-10. doi: 10.1055/s-0034-1371707

55. Grollmuss O, Gonzalez P. Non-invasive cardiac output measurement in low and very low birth weight infants: a method comparison. Front Pediatr. (2014) 2:16. doi: 10.3389/fped.2014.00016

56. Hsu KH, Wu TW, Wang YC, Lim WH, Lee CC, Lien R. Hemodynamic reference for neonates of different age and weight: a pilot study with electrical cardiometry. J Perinatol. (2016) 36:481-5. doi: 10.1038/jp.2016.2

57. Hsu KH, Wu TW, Wu IH, Lai MY, Hsu SY, Huang HW, et al. Electrical cardiometry to monitor cardiac output in preterm infants with patent ductus arteriosus: a comparison with echocardiography. Neonatology. (2017) 112:231-7. doi: 10.1159/000475774

58. Vaisbourd Y, Sharif D, Riskin A, Yaniv L, Dinur G, Amen K, et al. The effect of patent ductus arteriosus on coronary artery blood flow in premature infants: a prospective observational pilot study. J Perinatol. (2020) 40:1366-74. doi: 10.1038/s41372-020-0622-4

59. Naulaers G, Meyns B, Miserez M, Leunens V, Van Huffel S, Casaer P, et al. Use of tissue oxygenation index and fractional tissue oxygen extraction as noninvasive parameters for cerebral oxygenation. A validation study in piglets. Neonatology. (2007) 92:120-6. doi: 10.1159/000101063

60. Scheeren TW, Schober P, Schwarte LA. Monitoring tissue oxygenation by near infrared spectroscopy (NIRS): background and current applications. $J$ Clin Monit Comput. (2012) 26:279-87. doi: 10.1007/s10877-012-9348-y

61. Sood BG, McLaughlin K, Cortez J. Near-infrared spectroscopy: applications in neonates. Semin Fetal Neonatal Med. (2015) 20:164-72. doi: 10.1016/j.siny.2015.03.008

62. Pellicer A, Bravo Mdel C. Near-infrared spectroscopy: a methodologyfocused review. Semin Fetal Neonatal Med. (2011) 16:42-9. doi: 10.1016/j.siny.2010.05.003

63. Petrova A, Bhatt M, Mehta R. Regional tissue oxygenation in preterm born infants in association with echocardiographically significant patent ductus arteriosus. J Perinatol. (2011) 31:460-4. doi: 10.1038/jp.2010.200

64. Arman D, Sancak S, Gürsoy T, Topcuoglu S, Karatekin G, Ovali F. The association between NIRS and Doppler ultrasonography in preterm infants with patent ductus arteriosus. J Matern Fetal Neonatal Med. (2020) 33:124552. doi: 10.1080/14767058.2019.1639661

65. Alderliesten T, Dix L, Baerts W, Caicedo A, van Huffel S, Naulaers G, et al. Reference values of regional cerebral oxygen saturation during the first 3 days of life in preterm neonates. Pediatr Res. (2016) 79:55-64. doi: 10.1038/pr.2015.186

66. McNeill S, Gatenby JC, McElroy S, Engelhardt B. Normal cerebral, renal and abdominal regional oxygen saturations using near-infrared spectroscopy in preterm infants. J Perinatol. (2011) 31:51-7. doi: 10.1038/jp. 2010.71

67. Dix LM, van Bel F, Baerts W, Lemmers PM. Comparing nearinfrared spectroscopy devices and their sensors for monitoring regional cerebral oxygen saturation in the neonate. Pediatr Res. (2013) 74:557-63. doi: 10.1038/pr.2013.133

68. Urlesberger B, Kratky E, Rehak T, Pocivalnik M, Avian A, Czihak J, et al. Regional oxygen saturation of the brain during birth transition of term infants: comparison between elective cesarean and vaginal deliveries. $J$ Pediatr. (2011) 159:404-8. doi: 10.1016/j.jpeds.2011.02.030

69. Baik N, Urlesberger B, Schwaberger B, Schmölzer GM, Mileder L, Avian $A$, et al. Reference ranges for cerebral tissue oxygen saturation index in term neonates during immediate neonatal transition after birth. Neonatology. (2015) 108:283-6. doi: 10.1159/000438450 
70. Bailey SM, Hendricks-Munoz KD, Mally P. Cerebral, renal, and splanchnic tissue oxygen saturation values in healthy term newborns. Am J Perinatol. (2014) 31:339-44. doi: 10.1055/s-0033-1349894

71. Roche-Labarbe N, Carp SA, Surova A, Patel M, Boas DA, Grant PE, et al. Noninvasive optical measures of CBV, StO(2), CBF index, and $\mathrm{rCMRO}(2)$ in human premature neonates' brains in the first six weeks of life. Hum Brain Mapp. (2010) 31:341-52. doi: 10.1002/hbm.20868

72. Hyttel-Sorensen S, Pellicer A, Alderliesten T, Austin T, van Bel F, Benders $\mathrm{M}$, et al. Cerebral near infrared spectroscopy oximetry in extremely preterm infants: phase II randomised clinical trial. Bmj. (2015) 350:g7635. doi: 10.1136/bmj.g7635

73. Underwood MA, Milstein JM, Sherman MP. Near-infrared spectroscopy as a screening tool for patent ductus arteriosus in extremely low birth weight infants. Neonatology. (2007) 91:134-9. doi: 10.1159/000097131

74. Chock VY, Rose LA, Mante JV, Punn R. Near-infrared spectroscopy for detection of a significant patent ductus arteriosus. Pediatr Res. (2016) 80:67580. doi: $10.1038 /$ pr.2016.148

75. Dix L, Molenschot M, Breur J, de Vries W, Vijlbrief D, Groenendaal $\mathrm{F}$, et al. Cerebral oxygenation and echocardiographic parameters in preterm neonates with a patent ductus arteriosus: an observational study. Arch Dis Child Fetal Neonatal Ed. (2016) 101:F520-f6. doi: 10.1136/archdischild-2015-309192

76. Lemmers PM, Benders MJ, D’Ascenzo R, Zethof J, Alderliesten T, Kersbergen KJ, et al. Patent Ductus Arteriosus and Brain Volume. Pediatrics. (2016) 137:e20153090. doi: 10.1542/peds.2015-3090

77. Weisz DE, More K, McNamara PJ, Shah PS. PDA ligation and health outcomes: a meta-analysis. Pediatrics. (2014) 133:e1024-46. doi: 10.1542/peds.2013-3431

78. Lemmers PM, Toet MC, van Bel F. Impact of patent ductus arteriosus and subsequent therapy with indomethacin on cerebral oxygenation in preterm infants. Pediatrics. (2008) 121:142-7. doi: 10.1542/peds.2007-0925

79. Meier SD, Eble BK, Stapleton GE, Morales DL, Chang AC, Andropoulos DB. Mesenteric oxyhemoglobin desaturation improves with patent ductus arteriosus ligation. J Perinatol. (2006) 26:562-4. doi: 10.1038/sj.jp.7211559

80. Michel-Macías C, Morales-Barquet DA, Martínez-García A, Ibarra-Ríos D. Findings from somatic and cerebral near-infrared spectroscopy and echocardiographic monitoring during ductus arteriosus ligation: description of two cases and review of literature. Front Pediatr. (2020) 8:523. doi: $10.3389 /$ fped.2020.00523

81. Alderliesten T, Lemmers PM, van Haastert IC, de Vries LS, Bonestroo HJ, Baerts W, et al. Hypotension in preterm neonates: low blood pressure alone does not affect neurodevelopmental outcome. J Pediatr. (2014) 164:986-91. doi: 10.1016/j.jpeds.2013.12.042

82. Dempsey EM, Al Hazzani F, Barrington KJ. Permissive hypotension in the extremely low birthweight infant with signs of good perfusion. Arch Dis Child Fetal Neonatal Ed. (2009) 94:F241-4. doi: 10.1136/adc.2007.124263

83. Shelley KH. Photoplethysmography: beyond the calculation of arterial oxygen saturation and heart rate. Anesth Analg. (2007) 105 (6 Suppl.):S31-6, tables of contents. doi: 10.1213/01.ane.0000269512.82836.c9

84. Lima AP, Beelen P, Bakker J. Use of a peripheral perfusion index derived from the pulse oximetry signal as a noninvasive indicator of perfusion. Crit Care Med. (2002) 30:1210-3. doi: 10.1097/00003246-200206000-00006

85. Piasek CZ, Van Bel F, Sola A. Perfusion index in newborn infants: a noninvasive tool for neonatal monitoring. Acta Paediatr. (2014) 103:468-73. doi: 10.1111/apa.12574

86. De Felice C, Latini G, Vacca P, Kopotic RJ. The pulse oximeter perfusion index as a predictor for high illness severity in neonates. Eur J Pediatr. (2002) 161:561-2. doi: 10.1007/s00431-002-1042-5

87. Sahni R, Schulze KF, Ohira-Kist K, Kashyap S, Myers MM, Fifer WP. Interactions among peripheral perfusion, cardiac activity, oxygen saturation, thermal profile and body position in growing low birth weight infants. Acta Paediatr. (2010) 99:135-9. doi: 10.1111/j.1651-2227.2009.01514.x

88. Granelli A, Ostman-Smith I. Noninvasive peripheral perfusion index as a possible tool for screening for critical left heart obstruction. Acta Paediatr. (2007) 96:1455-9. doi: 10.1111/j.1651-2227.2007.00439.x

89. Kinoshita M, Hawkes CP, Ryan CA, Dempsey EM. Perfusion index in the very preterm infant. Acta Paediatr. (2013) 102:e398-401. doi: 10.1111/apa.12322
90. Kluckow M, Evans N. Superior vena cava flow in newborn infants: a novel marker of systemic blood flow. Arch Dis Child Fetal Neonatal Ed. (2000) 82:F182-7. doi: 10.1136/fn.82.3.f182

91. Takahashi S, Kakiuchi S, Nanba Y, Tsukamoto K, Nakamura T, Ito Y. The perfusion index derived from a pulse oximeter for predicting low superior vena cava flow in very low birth weight infants. J Perinatol. (2010) 30:265-9. doi: 10.1038/jp.2009.159

92. Bagci S, Müller N, Müller A, Heydweiller A, Bartmann P, Franz AR. A pilot study of the pleth variability index as an indicator of volume-responsive hypotension in newborn infants during surgery. J Anesth. (2013) 27:192-8. doi: 10.1007/s00540-012-1511-6

93. Khositseth A, Muangyod N, Nuntnarumit P. Perfusion index as a diagnostic tool for patent ductus arteriosus in preterm infants. Neonatology. (2013) 104:250-4. doi: 10.1159/000353862

94. Gomez-Pomar E, Makhoul M, Westgate PM, Ibonia KT, Patwardhan A, Giannone PJ, et al. Relationship between perfusion index and patent ductus arteriosus in preterm infants. Pediatr Res. (2017) 81:775-9. doi: $10.1038 /$ pr.2017.10

95. da Graca RL, Hassinger DC, Flynn PA, Sison CP, Nesin M, Auld PA. Longitudinal changes of brain-type natriuretic peptide in preterm neonates. Pediatrics. (2006) 117:2183-9. doi: 10.1542/peds.2005-1387

96. Letshwiti JB, Sirc J, O’Kelly R, Miletin J. Serial N-terminal pro-brain natriuretic peptide measurement as a predictor of significant patent ductus arteriosus in preterm infants beyond the first week of life. Eur J Pediatr. (2014) 173:1491-6. doi: 10.1007/s00431-014-2350-2

97. Ibara S, Tokunaga M, Ikenoue T, Murata Y, Hirano T, Asano H, et al. Histologic observation of the ductus arteriosus in premature infants with intrauterine growth retardation. J Perinatol. (1994) 14:411-6

98. El-Khuffash AF, Amoruso M, Culliton M, Molloy EJ. N-terminal pro-Btype natriuretic peptide as a marker of ductal haemodynamic significance in preterm infants: a prospective observational study. Arch Dis Child Fetal Neonatal Ed. (2007) 92:F421-2. doi: 10.1136/adc.2007.119701

99. Occhipinti F, De Carolis MP, De Rosa G, Bersani I, Lacerenza S, Cota F, et al. Correlation analysis between echocardiographic flow pattern and $\mathrm{N}$-terminal-pro-brain natriuretic peptide for early targeted treatment of patent ductus arteriosus. J Matern Fetal Neonatal Med. (2014) 27:1800-4. doi: 10.3109/14767058.2014.880879

100. El-Khuffash AF, Slevin M, McNamara PJ, Molloy EJ. Troponin T, Nterminal pro natriuretic peptide and a patent ductus arteriosus scoring system predict death before discharge or neurodevelopmental outcome at 2 years in preterm infants. Arch Dis Child Fetal Neonatal Ed. (2011) 96:F133-7. doi: 10.1136/adc.2010.185967

101. Khan SS, Sithisarn T, Bada HS, Vranicar M, Westgate PM, Hanna M. Urinary NT-proBNP levels and echocardiographic parameters for patent ductus arteriosus. J Perinatol. (2017) 37:1319-24. doi: 10.1038/jp.2017.139

102. Tosse V, Pillekamp F, Verde P, Hadzik B, Sabir H, Mayatepek E, et al. Urinary NT-proBNP, NGAL, and H-FABP may predict hemodynamic relevance of patent ductus arteriosus in very low birth weight infants. Neonatology. (2012) 101:260-6. doi: 10.1159/000334826

103. Czernik C, Metze B, Müller C, Bührer C. Urinary NT-proBNP and ductal closure in preterm infants. J Perinatol. (2013) 33:212-7. doi: $10.1038 /$ jp. 2012.86

104. Celik IH, Erdeve O, Demirel G, Canpolat FE, Dilmen U. Elevated urinary NT-proBNP after pharmacological closure of patent ductus arteriosus in very low birth weight infants. Early Hum Dev. (2013) 89:187-9. doi: 10.1016/j.earlhumdev.2012.09.020

105. Kahveci H, Tayman C, Laloglu F, Kavas N, Ciftel M, Yilmaz O, et al. Relationship between hemodynamically significant ductus arteriosus and ischemia-modified albumin in premature infants. Indian J Clin Biochem. (2016) 31:231-6. doi: 10.1007/s12291-0150523-z

106. Dix LM, Blok CA, Lemmers PM, van der Aa N, Molenschot MC, Vreman HJ, et al. Early end-tidal carbon monoxide levels, patency of the ductus arteriosus and regional cerebral oxygenation in preterm infants. Neonatology. (2014) 105:161-5. doi: 10.1159/000356167

107. Bin-Nun A, Mimouni FB, Fink D, Sela H, Hammerman C. elevated nucleated red blood cells at birth predict hemodynamically significant patent ductus arteriosus. J Pediatr. (2016) 177:313-5. doi: 10.1016/j.jpeds.2016.07.005 
108. Alyamac Dizdar E, Ozdemir R, Sari FN, Yurttutan S, Gokmen T, Erdeve $\mathrm{O}$, et al. Low platelet count is associated with ductus arteriosus patency in preterm newborns. Early Hum Dev. (2012) 88:813-6. doi: 10.1016/j.earlhumdev.2012.05.007

109. Kahvecioglu D, Erdeve O, Akduman H, Ucar T, Alan S, Çakir U, et al. Influence of platelet count, platelet mass index, and platelet function on the spontaneous closure of ductus arteriosus in the prematurity. Pediatr Neonatol. (2018) 59:53-7. doi: 10.1016/j.pedneo.2017.01.006

110. Bixler GM, Powers GC, Clark RH, Walker MW, Tolia VN. Changes in the diagnosis and management of patent ductus arteriosus from 2006 to 2015 in united states neonatal intensive care units. J Pediatr. (2017) 189:105-12. doi: $10.1016 /$ j.jpeds.2017.05.024
Conflict of Interest: The authors declare that the research was conducted in the absence of any commercial or financial relationships that could be construed as a potential conflict of interest.

Copyright (๑) 2021 Patra, Thakkar, Makhoul and Bada. This is an open-access article distributed under the terms of the Creative Commons Attribution License (CC BY). The use, distribution or reproduction in other forums is permitted, provided the original author(s) and the copyright owner(s) are credited and that the original publication in this journal is cited, in accordance with accepted academic practice. No use, distribution or reproduction is permitted which does not comply with these terms. 